\title{
Changes in Quality Attributes During Storage of Litchi Juice Treated With Dimethyl Dicarbonate (DMDC) and Nisin
}

\author{
Huanli Guo ${ }^{1,2}$, Yuanshan $\mathrm{Yu}^{1}$, Gengsheng Xiao ${ }^{1}$, Yujuan $\mathrm{Xu}^{1} \&$ Jijun $\mathrm{Wu}^{1}$ \\ ${ }^{1}$ Sericultural \& Agri-Food Research Institute, Guangdong Academy of Agricultural Sciences, Guangzhou, \\ China \\ ${ }^{2}$ College of Bioscience and Bioengineering, JiangXi Agricultural University, Nanchang, 330045 China \\ Correspondence: Gengsheng Xiao, Sericulture and Agri-food Research Institute, Dong Guang Zhuang RD., Tian \\ He District, Guangzhou, P. R. China. Tel: 86-020-8723-7279. E-mail: 499072725@qq.com
}

Received: April 19, 2015 Accepted: May 29, 2015 Online Published: June 3, 2015

doi:10.5539/jfr.v4n4p81 URL: http://dx.doi.org/10.5539/jfr.v4n4p81

\begin{abstract}
The aim of this work was to evaluate the change in the quality of litchi juice treated by DMDC combined with Nisin during storage of $4{ }^{\circ} \mathrm{C}$. Results found that addition of $250 \mathrm{mg} / \mathrm{L}$ of DMDC combined with $100 \mathrm{IU} / \mathrm{mL}$ of Nisin can ensure the microbiological safe of litchi juice during storage at $4{ }^{\circ} \mathrm{C}$. Compare with heat treatment $\left(95^{\circ} \mathrm{C}, 1 \mathrm{~min}\right)$, the treatment of DMDC combined with Nisin can retain a more value of sensory attributes, but a more loss in the content of total phenolics, ascorbic acid, and antioxidant capacity was observed during storage at $4{ }^{\circ} \mathrm{C}$ because of the ineffectiveness of DMDC and Nisin to the oxidase of litchi juice. Moreover, no significant change $(P>0.05)$ was observed in the value of $L * a *, b *$, and $\Delta \mathrm{E}$ in the heat-treated litchi juice, and yet the litchi juice treated by DMDC and Nisin gradually turned into light red at the end of storage because of the oxidation of phenolics by residual POD in the litchi juice, which resulted in a significant changes $(P<0.05)$ in the value of $L *, a *, b *$, and $\Delta \mathrm{E}$ in the litchi juice. This study would provide technical support for commercial application of DMDC combined with Nisin in litchi juice processing.
\end{abstract}

Keywords: litchi juice, Dimethyl Dicarbonate (DMDC), nisin, quality, storage

\section{Introduction}

Litchi (Litchi chinensis Sonn.) is a non-climacteric subtropical fruit with high commercial value for sweet and juicy flesh and attractive bright red pericarp. Apart from being consumed freshly, litchi fruit is also processed into juice, canned litchi and dried fruits. Litchi juice is enriched with sugar, minerals, vitamin, and various antioxidants and widely appreciated flavor, and thus it is able to compete in the market of fruit juices (Wu et al., 2007; Zeng et al., 2008; Saxena et al., 2011). But litchi juice is a low-acid food with an approximate pH of 4.5-5.0, so it has a higher risk of microbial contamination than more acidic foods, such as apple juice and orange juice. Some yeast and lactic acid bacteria grow quickly in litchi juice, which can cause spoilage and produce undesirable organoleptic changes in products ( $\mathrm{Li}$ et al., 2012). Therefore, litchi juices should undergo some type of preservation to ensure product quality and safety.

Thermal processing is the most straightforward means to inactivate the microorganism and enzymes in fruit juices and which are generally at $70-121^{\circ} \mathrm{C}$ for $30-120 \mathrm{~s}$ ( $\mathrm{Li}$ et al., 2012). But many juice producers, especially small seasonal operators, are unable to use thermal processing for economic reasons or opposed to thermal processing because of perceived undesirable effects on product quality and acceptability. Therefore, low-temperature alternatives are being sought: particular attention has been given to the use of antimicrobials (Cao et al., 2012; Yu et al., 2013).

DMDC (dimethyl dicarbonate), a dicarbonic acid ester, is a powerful antimicrobial agent due to its potential high reaction capacity with nucleophilic groups of enzymes from microorganisms, such as imidazoles, amines, or thiols, and which results in the rapid inactivation of microorganisms (Golden et al., 2005). In 1988, dimethyl dicarbonate (DMDC) (Velcorin) was first approved for use as an inhibitor of yeasts in wine and ready to drink tea beverages; and subsequently in 1996, approved as a yeast inhibitor in spirit drinks and in carbonated or non-carbonated, non-flavored beverages containing added electrolytes, juice sparklers, dilute beverages containing juice, fruit flavor, or both, with juice content not to exceed $50 \%$, at a concentration of $250 \mathrm{mg} / \mathrm{L}$ (FDA, 
1996; Golden et al., 2005). In addition, as of 2000, there is an effective notification for the use of DMDC as a microbial control agent in noncarbonated juice beverages containing up to and including $100 \%$ juice (FDA, 2000). Nisin is a heat-stable antimicrobial peptide produced by certain strains of Lactococcus lactis subsp. lactis (De Vuyst, 1994), and it is the only bacteriocin recognized as safe for the food industry by the World Health Organization (De Arauz et al., 2009; Li et al., 2012). Nisin exhibits antimicrobial activity toward a wide range of Gram-positive bacteria in juices (Li et al., 2012; Zhao et al., 2013).

The efficiency of DMDC against microorganism depends on the strain, initial cell concentration, temperature, pH, and kinds of juice beverages (Fisher et al., 1998; Williams et al., 2005). Some bacteria in juice are very resistant to DMDC, especially Leuconostoc mesenteroides. So individual addition of $250 \mathrm{mg} / \mathrm{L}$ DMDC to juice cannot completely kill and control some bacteria of juice, especially the low-acid juice (Yu et al., 2013a). Nisin had been evaluated for its efficacy in enhancing the inactivation of DMDC to bacteria of litchi juice in our previous study, and results showed that the treatment of DMDC combined with nisin offers a useful alternative to conventional heat treatment for controlling microbial growth and significantly extending the shelf-life of litchi juice (Yu et al., 2013a).

The aim of this work was to compare the effects of DMDC combined with nisin, and thermal pasteurization $\left(95{ }^{\circ} \mathrm{C} / 1 \mathrm{~min}\right)$ on the quality attributes of litchi juice during storage of $4{ }^{\circ} \mathrm{C}$. This study would provide technical support for commercial application of DMDC combined with Nisin in litchi juice processing.

\section{Materials and methods}

\subsection{Litchi Juice Preparation}

Litchi fruit (cv. Fei zi xiao) at 95\% maturation was harvested from a commercial orchard in Guangzhou, China. The peeled and destined litchi fruits were processed with a pulper (Midea Co., Guangdong), and passed through filter cloth $(100 \mathrm{mesh})$. And then the pulps were centrifuged at $3000 \times \mathrm{g}$ for $5 \mathrm{~min}$, and the supernatant was collected as fresh litchi juice.

\subsection{Preparation of Nisin Solution}

Nisin stock solution $(20000 \mathrm{IU} / \mathrm{ml})$ was prepared by dissolving commercial nisin powder $\left(10^{6} \mathrm{IU} / \mathrm{g}\right.$, Zhejiang Silver-Elephant Bio-engineering Co., Zhejiang, China) in a $0.05 \mathrm{M}$ of citric acid solution. Nisin stock solution was sterilized by immersed in boiling water $\left(100{ }^{\circ} \mathrm{C}\right)$ for $5 \mathrm{~min}$, and stored in the refrigerator of $4{ }^{\circ} \mathrm{C}$ after cooling (no more than 6 days).

\subsection{Thermal Pasteurization of Litchi Juice}

Fresh litchi juice was thermally processed $\left(95^{\circ} \mathrm{C}, 1 \mathrm{~min}\right)$ in a tubular heat exchanger (Shanghai pilotech Equipment Co., Ltd., China). After heating, the juice was manually filled under hygienic conditions into aseptic PET bottles, and immediately cooled down to $15 \pm 2{ }^{\circ} \mathrm{C}$ by a cooled water bath.

\subsection{DMDC and Nisin Treatment of Litchi Juice}

After fresh litchi juice was cooled to $4 \pm 1{ }^{\circ} \mathrm{C}, 100 \mathrm{IU} / \mathrm{mL}$ of Nisin and $250 \mathrm{mg} / \mathrm{L}$ of DMDC was added to the fresh litchi juice, immediately mixed vigorously, and then the litchi juice above was divided into aseptic PET bottles under hygienic conditions.

\subsection{Storage and Sampling}

The PET bottles were stored in the refrigerator of $4 \pm 2{ }^{\circ} \mathrm{C}$, and taken out at a regular interval for further analysis.

\subsection{Microbial Analysis}

Each sample was serially diluted with sterile $0.85 \% \mathrm{NaCl}$ solution, and then the dilution was used for microbial enumeration by pour plate methods. The viable cells of total aerobic bacteria were enumerated on the Plate Count Agar (PCA, Guangzhou HuanKai Microbiological Technology Co. Ltd., China), and the incubation was performed at $37^{\circ} \mathrm{C}$ for 2 days. The Rose Bengal Chloramphenicol Agar (Guangzhou HuanKai Microbiological Technology Co. Ltd., Guangdong, China) was used for detecting the viable cells of yeast and molds, and the incubation was performed at $30^{\circ} \mathrm{C}$ for 3 days. The total viable cells of lactic acid bacteria were detected using MRS agar (Guangzhou HuanKai Microbiological Technology Co. Ltd.). The MRS agar plates were incubated at $30^{\circ} \mathrm{C}$ for 2 to 3 days. Each test was performed in duplicate and results were expressed as colony-forming units (CFU) per milliliter. Rose bengal agar (Guangzhou HuanKai Microbiological Technology Co. Ltd., China) was used for counting the molds and yeasts after incubating at $28{ }^{\circ} \mathrm{C}$ for $72-120 \mathrm{~h}$. 


\subsection{Determination of $\mathrm{pH}$, Titratable Acidity and Total Soluble Solids (TSS)}

TSS were determined with a refractometer (Model RP-101, Atago Co. Ltd, Tokyo, Japan) at $20{ }^{\circ} \mathrm{C}$ and expressed in degree Brix ( ${ }^{\circ}$ Brix). The $\mathrm{pH}$ was determined using a $\mathrm{pH}$ meter (Metrohm744, Netherland) with a glasselectrode. Titratable acidity values were obtained by titrating $10 \mathrm{~mL}$ of juice with $0.1 \mathrm{~mol} / \mathrm{L} \mathrm{NaOH}$ to $\mathrm{pH}$ 8.1, expressing the results as $\mathrm{g}$ of citric acid per $100 \mathrm{~mL}$.

\subsection{Determination of Polyphenol Oxidase (PPO), and Peroxidase (POD) Activity}

The activity of PPO was assayed by a spectrophotometric method (Yingsanga et al., 2008) with some modifications. Catechol was chosen as the substrate. The reaction mixture contained $20 \mu \mathrm{l}$ sample juice and 2.5 $\mathrm{ml}$ substrate solution $(10 \mathrm{mM}$ catechol in $50 \mathrm{mM}$ phosphate buffer, $\mathrm{pH} \mathrm{7.0)}$. The absorbance of the mixture was measured at $420 \mathrm{~nm}$ for $3 \mathrm{~min}$ at $1 \mathrm{~min}$ intervals at $30{ }^{\circ} \mathrm{C}$ immediately after incubation in a spectrophotometer (UV-2450, Shimadzu Co., Japan) with a peltier thermostatic cell holder.

The activity of POD was also assayed by a spectrophotometric method (Yingsanga et al., 2008). The reaction mixture contained $50 \mu \mathrm{l}$ of sample juice and $2.95 \mathrm{ml}$ of substrate solution $(0.1 \mathrm{~mL} 4.0 \%$ guaiacol solution, dissolved with $50 \%$ ethanol; $0.1 \mathrm{~mL} 0.46 \% \mathrm{H}_{2} \mathrm{O}_{2} ; 2.75 \mathrm{~mL} 0.1 \mathrm{M}$ phosphate buffer, $\mathrm{pH}$ 5.5). The absorbance of the mixture was measured at $470 \mathrm{~nm}$ for $5 \mathrm{~min}$ at $1 \mathrm{~min}$ intervals at $30{ }^{\circ} \mathrm{C}$ immediately after incubation in a spectrophotometer (UV-2450, Shimadzu Co., Japan) with a peltier thermostatic cell holder.

One unit of PPO or POD activity was defined as a change in absorbance of $0.001 \mathrm{OD} / \mathrm{min}$ of each microlitre of litchi juice. The relative activities of PPO or POD were obtained with the following formula:

$$
\text { Residual activity }=\frac{\text { Specific activity of PPO or POD in the treated litchi juice }}{\text { Specific activity of PPO or POD in fresh litchi juice }} \times 100 \%
$$

\subsection{Determination of Ascorbic Acid, Total Polyphenols, and Antioxidant Capacity}

Ascorbic acid was determined by HPLC method using an Agilent system. The litchi juice $(1 \mathrm{~mL})$ was mixed with $1 \mathrm{~mL}$ of metaphosphoric acid $(6 \%, \mathrm{v} / \mathrm{v})$ aqueous solution, centrifuged at $10000 \mathrm{~g}(5 \mathrm{~min})$, and then the supernatant was used for further HPLC analysis (Hernandez, Lobo, \& Gonzalez, 2006). Ascorbic acid was separated on an Agilent ZORBAX SB-Aq $(4.6 \times 250 \mathrm{~mm})$ column using $0.02 \mathrm{~mol} / \mathrm{L}\left(\mathrm{NH}_{4}\right)_{2} \mathrm{HPO}_{4}$ aqueous solution ( $\mathrm{pH} 2.7$ ) as the mobile phase at a flow rate $1 \mathrm{~mL} / \mathrm{min}$ and $30^{\circ} \mathrm{C}$. Its content was detected using DAD detector at $254 \mathrm{~nm}$ and reported using external standards (L-ascorbic acid).

Total polyphenols were determined using the Folin-Ciocalteu method with some modifications (Singleton et al., 1965). In a $30 \mathrm{~mL}$ of test tube, $1 \mathrm{~mL}$ of litchi juice diluents (litchi juices diluted 20-50 folds with distilled water), and $2 \mathrm{~mL}$ of Folin-Ciocalteu reagent was added and mixed. After exactly $1 \mathrm{~min}, 2 \mathrm{ml}$ of sodium carbonate (10 $\mathrm{g} / 100 \mathrm{ml}$ ) was added and mixed, and allowed to stand at room temperature for $1 \mathrm{~h}$. The absorbance was read at $760 \mathrm{~nm}$ by a spectrophotometer (UV-1800, Shimadzu, Japan), and the total polyphenol concentration was calculated from a calibration curve $\left(\mathrm{R}^{2}=0.999\right)$, using pyrogallic acid as standard $(0-50 \mathrm{mg} / \mathrm{L})$.

The antioxidant capacity of litchi juice sample was evaluated by oxygen radical absorbance capacity (ORAC). ORAC assay was performed according to Ou et al. (2001) using the Infinite M200 microplate reader (Tecan Group Ltd., Switzerland). The $80 \mu \mathrm{L}$ of freshly prepared sodium fluorescein solution $(1.25 \mu \mathrm{M} / \mathrm{L}$ in $75 \mathrm{mM} / \mathrm{L}$ of phosphate buffer, $\mathrm{pH}$ 7.4) and $20 \mu \mathrm{L}$ litchi juice diluted with water was added into microplate wells for 5 min. Then, $100 \mu \mathrm{L}$ of freshly prepared 2, 2'-Azobis (2-methylpropionamidine) dihydrochloride $(140 \mathrm{mM} / \mathrm{L}$ in 75 $\mathrm{mM} / \mathrm{L}$ phosphate buffer, $\mathrm{pH} 7.4$ ) was also added in wells. Fluorescence was collected at $485 \mathrm{~nm}$ on excitation at $520 \mathrm{~nm}$ on emission, taking measurements every $150 \mathrm{~s}$ for $1.5 \mathrm{~h}$ at $37^{\circ} \mathrm{C}$. The standard curve was linear between 100 and $500 \mu \mathrm{M} / \mathrm{L}$ Trolox. The result was expressed as mM Trolox equivalent (TE)/L.

\subsection{Determination of Browning Degree and Color Analysis}

The browning degree (BD) of litchi juice was analyzed using a spectrophotometric method (Roig et al., 1999). Juice was centrifuged with a refrigerated Centrifuge (GL-166-A, Shanghai Anting Scientific Equipment Factory, Shanghai, China) at $10000 \mathrm{rpm} / \mathrm{min}$ at $4{ }^{\circ} \mathrm{C}$ for $5 \mathrm{~min}$, then passed through a $0.45 \mu \mathrm{m}$ cellulose nitrate membrane (Beijing Bomex Co., Beijing, China). The BD was determined by measuring the absorbance value at $420 \mathrm{~nm}$ using a spectrophotometer (UV-726 Shimadzu, Shanghai, China) at room temperature.

Color assessment was conducted using a color measurement spectrophotometer (HunterLab ColorQuest XE, Hunter Associates Laboratory, Inc., Virginia, USA) in the reflectance (transmission) mode. Color was expressed as $L^{*}$ (lightness; $0=$ black, 100=white), $a^{*}\left(-a^{*}=\right.$ greenness, $+a^{*}=$ redness) and $b^{*}\left(-b^{*}=\right.$ blueness, $+b^{*}=$ yellowness). Three measurements were performed, and the results were averaged. These values were then used to calculate the total color difference $(\Delta E)$ (Yu et al., 2013b). The calculated equations were as follows, where $L^{*}{ }_{0}, a^{*}{ }_{0}$ and 
$b^{*}{ }_{0}$ are the control values for fresh litchi juice samples:

$$
\Delta E=\sqrt{\left(L^{*}-L_{0}^{*}\right)^{2}+\left(a^{*}-a_{0} *\right)^{2}+\left(b^{*}-b_{0}^{*}\right)^{2}}
$$

\subsection{Sensory Analysis}

Sensory analysis of litchi juice was performed by a semi-trained panel composed by 15 panelists (12 and 39 year of age, equal distribution between male and female), using a 9-point hedonic scale for scoring odor, sweetness, acidity, color and overall acceptability (9 like very much, 1 dislike very much, and 5 as rejection point) (YeH et al., 1998; Walkling-Ribeiro et al., 2009; Lim 2011)

\subsection{Statistical Analysis}

For all kinds of samples, two different batches were considered and analyzed separately. All experiments were conducted in triplicate. Analysis of one-way ANOVA was accomplished with the software SPSS Statistics 19.0 (IBM Co., USA). Duncan's multiple range tests were used to determine statistically significant differences of variables at $95 \%$ confidence.

\section{Results and Discussion}

\subsection{Changes in the Indigenous Microorganism of Litchi Juice Treated With DMDC and Nisin During Storage}

After added $250 \mathrm{mg} / \mathrm{L}$ of DMDC and $100 \mathrm{IU} / \mathrm{mL}$ of Nisin to the fresh litchi juice at $4{ }^{\circ} \mathrm{C}$, the counts of total aerobic bacteria, lactic acid bacteria, yeast and mold in litchi juice linearly declined with increase of time during initial $6 \mathrm{~h}$, and the total aerobic bacteria, lactic acid bacteria, yeast and mold in litchi juice were not detected after $12 \mathrm{~h}$ and during 3-month storage, indicating that the juices were microbiologically safe in this study (Table 1). This study focused on the changes in quality of the juices during storage at $4{ }^{\circ} \mathrm{C}$, and the analyses concerning the changes were presented as the following. Moreover, the litchi juice processed by the thermal pasteurization $\left(95^{\circ} \mathrm{C}, 1 \mathrm{~min}\right)$, which was equivalent effects on the inactivation of microorganisms with the litchi juice treated with $250 \mathrm{mg} / \mathrm{L} \mathrm{DMDC}$ and $100 \mathrm{IU} / \mathrm{mL}$ of Nisin, was as the contrast for quality analysis.

Table 1. Changes of microbial counts ( $\mathrm{Lg} \mathrm{CFU} / \mathrm{mL}$ ) in the litchi juice treated with $250 \mathrm{mg} / \mathrm{L}$ of DMDC combined with $100 \mathrm{IU} / \mathrm{mL}$ of Nisin, and thermal pasteurization $\left(95^{\circ} \mathrm{C}, 1 \mathrm{~min}\right)$ during storage at $4{ }^{\circ} \mathrm{C}$

\begin{tabular}{|c|c|c|c|c|c|c|}
\hline & \multicolumn{3}{|l|}{ Heat-treated } & \multicolumn{3}{|c|}{ DMDC and Nisin treated } \\
\hline & $\begin{array}{l}\text { Total aerobic } \\
\text { bacteria }\end{array}$ & $\begin{array}{l}\text { Lactic acid } \\
\text { bacteria }\end{array}$ & Mold/Yeast & $\begin{array}{ll}\text { Total } & \text { aerobic } \\
\text { bacteria } & \end{array}$ & $\begin{array}{l}\text { Lactic acid } \\
\text { bacteria }\end{array}$ & Mold/Yeast \\
\hline $0 \mathrm{~d}$ & N.D. & N.D. & N.D. & N.D. & N.D. & N.D. \\
\hline $1 \mathrm{~d}$ & N.D. & N.D. & N.D. & N.D. & N.D. & N.D. \\
\hline $15 \mathrm{~d}$ & N.D. & N.D. & N.D. & N.D. & N.D. & N.D. \\
\hline $30 \mathrm{~d}$ & N.D. & N.D. & N.D. & N.D. & N.D. & N.D. \\
\hline $45 \mathrm{~d}$ & N.D. & N.D. & N.D. & N.D. & N.D. & N.D. \\
\hline $60 \mathrm{~d}$ & $0.61 \pm 0.04$ & N.D. & N.D. & $0.31 \pm 0.01$ & N.D. & N.D. \\
\hline $90 \mathrm{~d}$ & $0.70 \pm 0.06$ & N.D. & N.D. & $0.48 \pm 0.05$ & N.D. & N.D. \\
\hline
\end{tabular}

N.D.: Colony counts below the detection limit (1 CFU/mL).

\subsection{Changes of pH, Titratable Acidity and Total Soluble Solids}

The $\mathrm{pH}$, titratable acidity and total soluble solids of fresh litchi juice were $4.48 \pm 0.08,0.28 \pm 0.03 \mathrm{~g}$ of citric acid per $100 \mathrm{~mL}$, and $17.22 \pm 0.24^{\circ}$ Brix, respectively. Compared with untreated fresh litchi juice, no significant changes $(P>0.05)$ of $\mathrm{pH}$, titratable acidity and total soluble solids were observed as treated by DMDC combined with Nisin, and heat $\left(95^{\circ} \mathrm{C}, 1 \mathrm{~min}\right)$. And also, during storage of $90 \mathrm{~d}$ at $4{ }^{\circ} \mathrm{C}$, the $\mathrm{pH}$, titratable acidity and total soluble solids did not show significant changes $(P>0.05)$ in the litchi juice treated by DMDC combined with Nisin, and heat $\left(95^{\circ} \mathrm{C}, 1 \mathrm{~min}\right)$, which may related to the inhibition of growth of indigenous microorganism in the litchi juice. 


\subsection{Changes of PPO and POD Activity, Color and Browning Degree}

The POD activity of fresh litchi juice was $2206.6 \mathrm{IU} / \mathrm{mL}$. No PPO activity in the fresh litchi juice was detected which was similar to those described in the literature (Yang et al., 2010; Xu et al., 2014). The POD can be efficiently inactivated by the heat treatment $\left(95{ }^{\circ} \mathrm{C}, 1 \mathrm{~min}\right)$, and thus no POD activity was detected in the heat-treated litchi juice during storage of $90 \mathrm{~d}$ at $4{ }^{\circ} \mathrm{C}$. However, $85.6 \%$ of POD activity was residual after $12 \mathrm{~h}$ as added $250 \mathrm{mg} / \mathrm{L}$ of DMDC and $200 \mathrm{IU} / \mathrm{mL}$ of Nisin to the fresh litchi juice at $4{ }^{\circ} \mathrm{C}$, indicating the DMDC and Nisin cannot inactivate the POD (Figure 1). The POD activity of litchi juice treated by DMDC and Nisin did not showed significant decrease $(P>0.05)$ during initial $30 \mathrm{~d}$ at $4{ }^{\circ} \mathrm{C}$, and yet a fast decline of POD activity was observed at the end of storage (Figure 1), which may be attributed to the damage of native structure of POD protein (Davies \& Truscott, 2001; Müller et al., 2014).

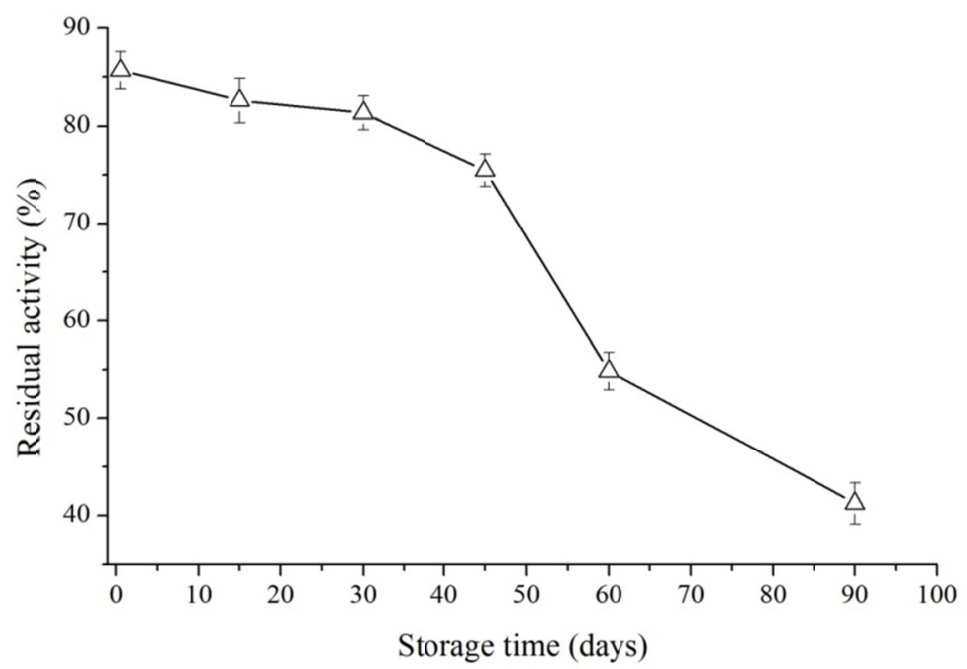

Figure 1. Changes of residual relative activity of POD in the litchi juice treated by DMDC combined with Nisin during storage at $4{ }^{\circ} \mathrm{C}$

Table 2. Changes of color parameters in litchi juice treated by DMDC combined with Nisin, and heat during storage at $4{ }^{\circ} \mathrm{C}$

\begin{tabular}{|c|c|c|c|c|c|}
\hline Storage time & $L^{*}$ & $a^{*}$ & $b^{*}$ & $\Delta \mathrm{E}$ & $\mathrm{BD}$ \\
\hline \multicolumn{6}{|c|}{ Heat-treated litchi jucie } \\
\hline $0 \mathrm{~d}$ & $81.08 \pm 0.27^{\mathrm{a}}$ & $-2.32 \pm 0.58^{\mathrm{a}}$ & $5.32 \pm 0.21^{\mathrm{c}}$ & $3.82 \pm 0.29^{b}$ & $0.12 \pm 0.01^{\mathrm{b}}$ \\
\hline $15 \mathrm{~d}$ & $81.66 \pm 0.24^{\mathrm{a}}$ & $-2.60 \pm 0.56^{\mathrm{a}}$ & $5.63 \pm 0.57^{\mathrm{c}}$ & $4.23 \pm 0.19^{b}$ & $0.12 \pm 0.01^{\mathrm{b}}$ \\
\hline $30 \mathrm{~d}$ & $81.54 \pm 0.14^{\mathrm{b}}$ & $-3.04 \pm 0.59^{\mathrm{a}}$ & $4.88 \pm 0.47^{\mathrm{c}}$ & $4.74 \pm 0.14^{\mathrm{c}}$ & $0.15 \pm 0.02^{b}$ \\
\hline $45 \mathrm{~d}$ & $81.19 \pm 0.23^{\mathrm{b}}$ & $-3.40 \pm 0.51^{\text {a }}$ & $4.78 \pm 0.36^{\mathrm{c}}$ & $4.99 \pm 0.20^{\mathrm{c}}$ & $0.17 \pm 0.01^{\mathrm{bc}}$ \\
\hline $60 \mathrm{~d}$ & $81.04 \pm 0.10^{\mathrm{b}}$ & $-3.38 \pm 0.48^{\mathrm{a}}$ & $4.72 \pm 0.15^{\mathrm{c}}$ & $5.06 \pm 0.53^{\mathrm{c}}$ & $0.18 \pm 0.02^{\mathrm{c}}$ \\
\hline $90 \mathrm{~d}$ & $80.93 \pm 0.12^{\mathrm{c}}$ & $-4.05 \pm 0.52^{\mathrm{a}}$ & $9.32 \pm 0.51^{\mathrm{d}}$ & $8.85 \pm 0.35^{\mathrm{e}}$ & $0.20 \pm 0.01^{\mathrm{e}}$ \\
\hline \multicolumn{6}{|c|}{ Litchi juice treated by DMDC combined with Nisin } \\
\hline $0.5 \mathrm{~d}$ & $81.95 \pm 1.42^{b}$ & $-2.49 \pm 0.31^{\mathrm{a}}$ & $1.64 \pm 0.01^{\mathrm{a}}$ & $2.92 \pm 0.01^{\mathrm{a}}$ & $0.09 \pm 0.01^{\mathrm{a}}$ \\
\hline $15 \mathrm{~d}$ & $83.77 \pm 1.84^{\mathrm{b}}$ & $-1.61 \pm 0.26^{b}$ & $2.75 \pm 0.04^{b}$ & $2.38 \pm 0.05^{\mathrm{a}}$ & $0.10 \pm 0.01^{\mathrm{a}}$ \\
\hline $30 \mathrm{~d}$ & $77.73 \pm 1.44^{\mathrm{d}}$ & $-1.36 \pm 0.22^{b}$ & $3.09 \pm 0.03^{b}$ & $7.23 \pm 0.12^{\mathrm{d}}$ & $0.13 \pm 0.01^{\mathrm{b}}$ \\
\hline $45 \mathrm{~d}$ & $76.72 \pm 1.04^{\mathrm{d}}$ & $0.01 \pm 0.16^{\mathrm{c}}$ & $4.14 \pm 0.26^{\mathrm{c}}$ & $8.86 \pm 0.19^{\mathrm{e}}$ & $0.17 \pm 0.02^{b c}$ \\
\hline $60 \mathrm{~d}$ & $76.09 \pm 1.25^{\mathrm{d}}$ & $0.62 \pm 0.34^{\mathrm{d}}$ & $5.58 \pm 0.35^{\mathrm{c}}$ & $10.10 \pm 0.26^{\mathrm{f}}$ & $0.17 \pm 0.01^{\mathrm{bc}}$ \\
\hline $90 \mathrm{~d}$ & $76.98 \pm 1.42^{\mathrm{d}}$ & $1.31 \pm 0.26^{\mathrm{e}}$ & $10.25 \pm 0.52^{\mathrm{d}}$ & $12.28 \pm 0.61^{\mathrm{g}}$ & $0.19 \pm 0.02^{\mathrm{d}}$ \\
\hline
\end{tabular}


Table 2 presented the changes in color parameters of litchi juice treated by DMDC combined with Nisin, and heat during storage at $4{ }^{\circ} \mathrm{C}$. No significant change $(P>0.05)$ was observed in $L^{*}, a *, b *$, and $\Delta \mathrm{E}$ value after $0.5 \mathrm{~d}$ as added DMDC and Nisin to fresh litchi juice (Table 1). During further storage, the $a * b *$, and $\Delta \mathrm{E}$ value showed a tendency to increase, and yet a tendency to decrease was observed in the $L^{*}$ value (Table 1 ). And the litchi juice treated by DMDC and Nisin gradually turned into light red at the end of storage. The changes in the color of litchi juice treated by DMDC combined with Nisin may be due to the enzymatic browning of residual POD in the litchi juice (Zhang \& Quantick, 1997). POD can oxidize phenols to quinones that in turn polymerize to form brown pigments (Yingsanga et al., 2008).

No significant changes in the $L^{*}$ and $a^{*}$ value were observed (Table 1), and yet the $b^{*}$ values of litchi juice showed slight increase because the caramelization reaction during heat treatment (Zhang et al., 2013). Unlike the juice treated by DMDC combined with Nisin, the value of $L * a *, b *$, and $\Delta \mathrm{E}$ in the heated-treated litchi juice did not showed significant changes during storage of the initial $60 \mathrm{~d}$ (Table 1), which may be attributed to the inactivation of POD by heat. And also the litchi juice treated by heat did not gradually turned into light red at the end of storage.

The (browning degree) BD value only showed a slow tendency to increase (Table 1). The increase of BD value during storage mainly was resulted in the Maillard reaction taking place between alphaamino groups and reducing sugars (Liu et al., 2012). The reaction rate of Maillard reaction can be slowed down by the low temperature. In this study, the storage temperature was $4{ }^{\circ} \mathrm{C}$, which can well inhibit the increase of BD value.

\subsection{Changes of Ascorbic Acid}

The fresh litchi juice initially contains a high ascorbic acid, reaching $230.16 \mathrm{mg} / \mathrm{L}$. A $94.9 \%$ loss of ascorbic acid were observed after $12 \mathrm{~h}$ as added $250 \mathrm{mg} / \mathrm{L}$ of DMDC and $100 \mathrm{IU} / \mathrm{mL}$ of Nisin to fresh litchi juice at $4{ }^{\circ} \mathrm{C}$. During further storage at $4{ }^{\circ} \mathrm{C}$, no ascorbic acid was detected in the litchi juices treated by DMDC and Nisin. Some studies reported that ascorbic acid barely reactive with DMDC or Nisin, and thus the loss of ascorbic acid in the litchi juice added with DMDC and Nisin could be due to the oxidation of ascorbic acid oxidase (Golden et al., 2005; Leong \& Oey, 2012). Generally, the oxidation of ascorbic acid in the fresh litchi juice can be inhibited by the growth of indigenous microorganism because of the depletion of dissolved oxygen of litchi juice by the indigenous microorganism. As adding DMDC and Nisin to fresh litchi juice, the indigenous microorganisms showed rapid inactivation. The inactivation of indigenous microorganisms would decrease the depletion of dissolved oxygen, resulting in the more ascorbic acid was oxidized (Leong \& Oey, 2012).

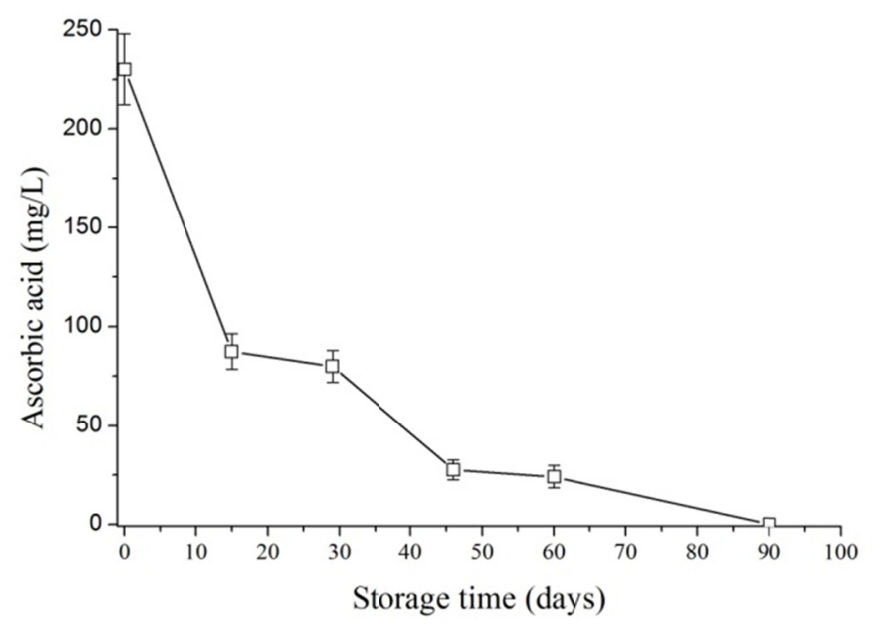

Figure 2. Changes in the contents of ascorbic acid in the heat-treated litchi juice during storage at $4{ }^{\circ} \mathrm{C}$

The heat treatment can retain ascorbic acid of litchi juice well, and thus only $3.4 \%$ loss of ascorbic acid was observed in litchi juice after treated by heat at $95{ }^{\circ} \mathrm{C}$ for $1 \mathrm{~min}$ (Figure 2). During further storage at $4{ }^{\circ} \mathrm{C}$, the contents of ascorbic acid in heat litchi juice showed a fast-to-slow tendency, and no ascorbic acid was detected in the heat-treated litchi juices after $90 \mathrm{~d}$ (Figure 2). Earlier studies had showed that ascorbic acid can degrade aerobically and anaerobically during storage, at the rates depending on storage conditions, packaging and the processing method employed (Kennedy et al., 1992; Kabasakalis et al., 2000). In the initial stage of storage, 
residual oxygen and ascorbic acid oxidase in heat treated litchi juice could accelerate the aerobic degradation of ascorbic acid, and when the oxygen was totally depleted, the anaerobic degradation of ascorbic acid occurred, whereas it has been reported that the aerobic degradation rate constants were 100 to 1000 times higher than the anaerobic degradation rate constants (Kabasakalis et al., 2000).

\subsection{Changes of Total Phenolics, and Antioxidant Capacity}

The content of total phenolics in fresh litchi juice reached $561.66 \mathrm{mg} / \mathrm{L}$. The content of total phenolics in the litchi juice showed a $19.9 \%$ of reduction after heat treatment at $95{ }^{\circ} \mathrm{C}$ for $1 \mathrm{~min}$, which could be caused by thermal degradation. The degradation of phenolic compounds during thermal processing had been observed in other studies (Klopotek et al., 2005). And a 22.9\% of reduction in the total phenolics was also observed after 12 $\mathrm{h}$ as added $250 \mathrm{mg} / \mathrm{L}$ of DMDC and $200 \mathrm{IU} / \mathrm{mL}$ of Nisin to litchi juice at $4{ }^{\circ} \mathrm{C}$. Similarly with the decrease of ascorbic acid, the inactivation of indigenous microorganisms by DMDC and Nisin would decrease the depletion of dissolved oxygen, resulting in the more phenolics was oxidized by POD (Zhang et al., 1997; Yingsangaa et al., 2008).

During further storage at $4{ }^{\circ} \mathrm{C}$, a tendency to decrease in the contents of total phenolics was in the heat-treated litchi juice, and the litchi juice added with DMDC and Nisin (Figure 3). And at the end of storage at $4{ }^{\circ} \mathrm{C}$, the rate of decrease in total phenolics in the litchi juice added with DMDC and Nisin was faster than heat-treated litchi juice. It is thought that loss of phenolics was probably due to oxidation as well as reciprocal condensation of phenolic compounds (Trewhella \& Grint, 1988; Castaňeda-Ovando et al., 2009). Condensation reactions of phenolic compounds naturally occurred in juices during storage, and condensation products were unstable and further degrade to colorless compounds (Es-Safi et al., 2003; Turkyilmaz \& Ozkan 2014). In addition, the residual POD in the litchi juice added with DMDC and Nisin can accelerate the oxidation of phenolic compounds, which will resulted in the enhancement of enzymatic browning in the litchi juice (Yingsangaa et al., 2008).
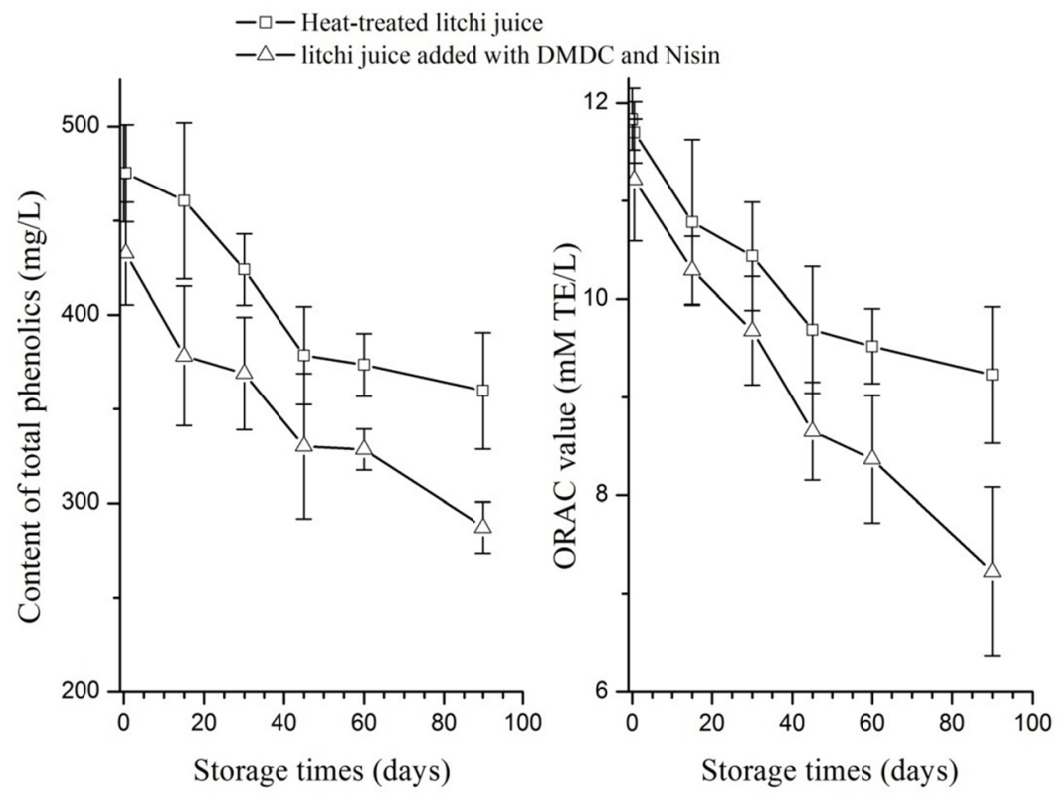

Figure 3. Changes in the content of total phenolics and antioxidant capacity (ORAC value) in the heat-treated litchi juices, and the litchi juice treated by DMDC combined with Nisin during storage at $4{ }^{\circ} \mathrm{C}$

The ORAC value of fresh litchi juice was $14.87 \mathrm{mM} \mathrm{TE} / \mathrm{L}$. The ORAC value showed a $20.4 \%$ reduction in litchi juice after heat treatment, and $24.6 \%$ of reduction was also observed after $12 \mathrm{~h}$ as added $250 \mathrm{mg} / \mathrm{L}$ of DMDC and $200 \mathrm{IU} / \mathrm{mL}$ of Nisin to litchi juice at $4{ }^{\circ} \mathrm{C}$. During further storage at $4{ }^{\circ} \mathrm{C}$, the ORAC value showed a tendency to decrease in the heat-treated litchi juice, and the litchi juice added with DMDC and Nisin, and the data trends for antioxidant capacity (ORAC value) and total phenolics content of both litchi juice seem to be positively associated (Figure 3), indicating that total phenols made greater contribution to the antioxidant 
capacity of litchi juices. Previous studies have demonstrated that phenolic compounds are responsible for antioxidant capacities in fruits, and the fruits with higher phenolic contents generally show stronger antioxidant capacities (Kalt et al., 1999; Da Silva et al., 2007).

\subsection{Changes of Sensory Attributes}

Comparing with the fresh litchi juice, no significant differences $(P>0.05)$ were detected by the panelists in the litchi juice in terms of odour, acidity, sweetness, and overall acceptability as added with $250 \mathrm{mg} / \mathrm{L}$ of DMDC and $200 \mathrm{IU} / \mathrm{mL}$ of Nisin to the litchi juice at $4{ }^{\circ} \mathrm{C}$ for $12 \mathrm{~h}$ (Figure 4). During further storage of $90 \mathrm{~d}$ at $4{ }^{\circ} \mathrm{C}$, no significant changes $(P>0.05)$ in the scores of odour, acidity, and sweetness were observed in the litchi juice treated with DMDC combined with Nisin, and yet the scores of overall acceptability showed a reduction of 1 scores at the end of storage because of the changes of color. Moreover, a greater number of panelists sensed slightly cooked or flavor and rough feel in heat-treated litchi juice, resulting in the decreased of scores in odour and overall acceptability (Figure 4). During further storage of $90 \mathrm{~d}$ at $4{ }^{\circ} \mathrm{C}$, no significant changes $(P>0.05)$ in the scores of odour, acidity, sweetness and overall acceptability were observed in the heat-treated litchi juice.

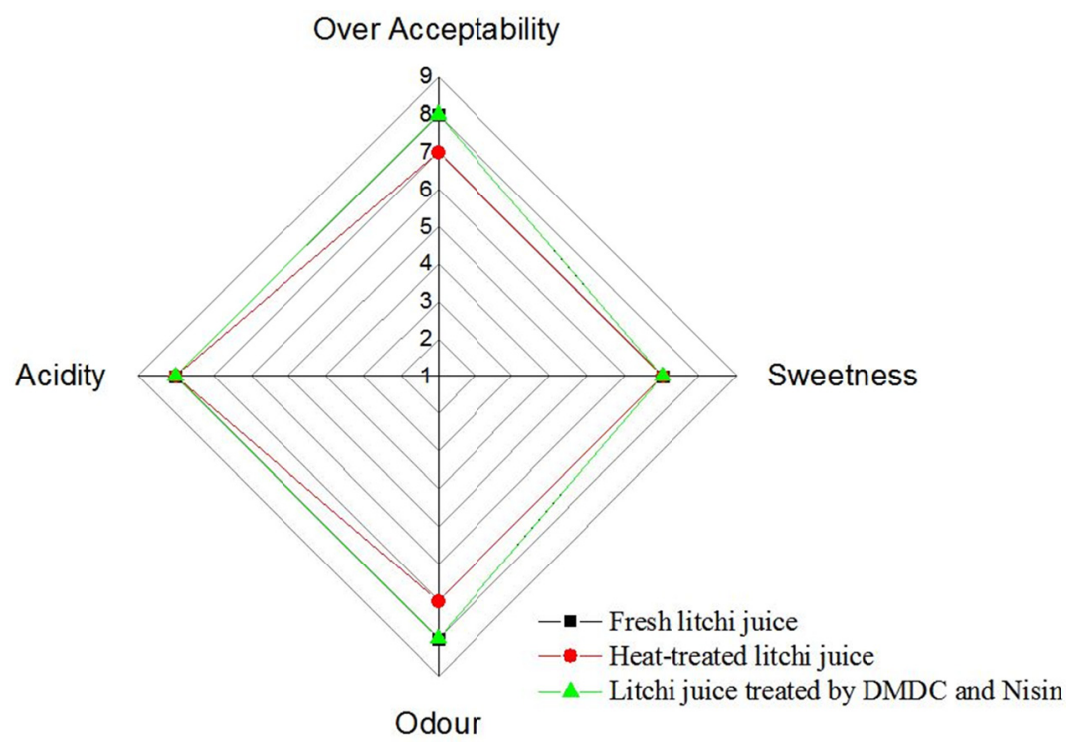

Figure 4. Sensory evaluation of odour, acidity, sweetness, and overall acceptability of litchi juice samples

\section{Conclusion}

Addition of DMDC combined with Nisin can ensure the microbiological safe of litchi juice during storage at $4{ }^{\circ} \mathrm{C}$. Compare with heat treatment $\left(95{ }^{\circ} \mathrm{C}, 1 \mathrm{~min}\right)$, which was equivalent effects on the inactivation of microorganisms with the litchi juice treated with $250 \mathrm{mg} / \mathrm{L}$ DMDC and $100 \mathrm{IU} / \mathrm{mL}$ of Nisin, the treatment of DMDC combined with Nisin can retain a more value of sensory attributes, but a more loss in the content of total phenolics, ascorbic acid, and antioxidant capacity was observed during storage at $4{ }^{\circ} \mathrm{C}$ because of the ineffectiveness of DMDC and Nisin to the oxidase of litchi juice. Moreover, no significant changes were observed in the value of $L *, a *, b *$, and $\Delta \mathrm{E}$ in the heat-treated litchi juice, and yet the litchi juice treated by DMDC and Nisin gradually turned into light red at the end of storage because of the oxidation of phenolics by residual POD in the litchi juice, which resulted in a significant changes $(P<0.05)$ in the value of $L *, a *, b *$, and $\triangle \mathrm{E}$ in the litchi juice. According to the results discussed above, it can be concluded that DMDC combined with Nisin treatment offers a useful alternative to conventional heat for controlling microbial growth and significantly extending the shelf-life of litchi juice as only considering the inactivation and inhibition of indigenous microorganism, but some treatments, which can inhibit the activity of residual oxidase in the litchi juice treated by DMDC combined with Nisin, will need be applied for well retaining the quality of litchi juice during storage at $4{ }^{\circ} \mathrm{C}$.

\section{Acknowledgments}

This research was supported by Project No. 31401531 of National Natural Science Fund, China, and Project of No. 2014J4100188 of Guangzhou City Science and Technology Plan, China. 


\section{References}

Cao, X., Zhang, Y., Zhang, F., Wang, Y., Yi, J., \& Liao, X. (2011). Effects of high hydrostatic pressure on enzymes, phenolic compounds, anthocyanins, polymeric color and color of strawberry pulps. Journal of the Science of Food and Agriculture, 91, 877-885. http://dx.doi.org/10.1002/jsfa.4260

Castaňeda-Ovando, A., De Pacheco-Hernández, M. L., De Páez-Hernández, M. E., Rodríguez, J. A., \& Galán-Vidal, C. A. (2009). Chemical studies of anthocyanins: A review. Food Chemistry, 113, 859-871. http://dx.doi.org/10.1016/j.foodchem.2008.09.001

Ciou, J., Lin, H., Chiang, P., Wang, C., \& Charles, A. L. (2011). The role of polyphenol oxidase and peroxidase in the browning of water caltrop pericarp during heat treatment. Food Chemistry, 127, 523-527. http://dx.doi.org/10.1016/j.foodchem.2011.01.034

Da Silva, F. L., Escribano-Bailón, M. T., Alonso, J. J. P., Rivas-Gonzalo, J. C., \& Santos-Buela, C. (2007). Anthocyanin pigments in strawberry. LWT-Food Science and Technology, 40, 374-382. http://dx.doi.org/10.1016/j.lwt.2005.09.018

Davies, M. J., \& Truscott, R. J. W. (2001). Photo-oxidation of proteins and its role in cataractogenesis. Journal of Photochemistry and Photobiology B: Biology, 63, 114-125. http://dx.doi.org/10.1016/S1011-1344(01)00208-1

De Arauz, L. J., Jozala, A. F., Mazzola, P. G., \& Vessoni Penna, T. C. (2009). Nisin biotechnological production and application: a review. Trends in Food Science and Technology, 20, 146-154. http://dx.doi.org/10.1016/j.tifs.2009.01.056

De Vuyst, L. (1994). Nisin production variability between natural Lactococcus Lactis subsp. Lactis strains. Biotechnology Letters, 16, 287-292. http://dx.doi.org/10.1007/BF00134627

Es-Safi, N., Cheynier, V., \& Moutounet, M. (2003). Implication of phenolic reactions in food organoleptic properties, Journal of Food Composition and Analysis, 16, 535-553. http://dx.doi.org/10.1016/S0889-1575(03)00019-X

FDA. (1996). Food additives permitted for direct addition to food for human consumption; dimethyl dicarbonate. Federal Register, 61, 26786-26788.

FDA. (2001). Food additives permitted for direct addition to food for human consumption; dimethyl dicarbonate. Federal Register, 66, 13652-13653.

Fisher, T. L., \& Golden, D. A. (1998). Survival of Escherichia coli O157:H7 in apple cider as affected by dimethyl dicarbonate, sodium bisulfite, and sodium benzoate. Journal of Food Science, 63, 904-906. http://dx.doi.org/10.1111/j.1365-2621.1998.tb17923.x

Golden D. A., Worobo, R. W., \& Ough, C. S. (2005). Dimethyl dicarbonate and diethyl dicarbonate. In P. M. Davidson, J. N. Sofos, \& A. L. Branen (Eds.), Antimicrobials in foods, 3rd ed., (pp. 305-327). New York: Taylor \& Francis Group, LLC.

Kabasakalis, V., Siopidou, D., \& Moshatou, E. (2000). Ascorbic acid content of commercial fruit juices and its rate of loss upon storage. Food Chemistry, 70, 325-328. http://dx.doi.org/10.1016/S0308-8146(00)00093-5

Kalt, W., Forney, C. F., Martin, A., \& Prior, R. L. (1999). Antioxidant capacity, vitamin C, phenolics, and anthocyanins after fresh storage of small fruits. Journal of Agriculture and Food Chemistry, 47, 4638-4644. http://dx.doi.org/10.1021/jf990266t

Kennedy, J. F, Rivera, Z. S, Lloyd, L. L, Warner, F. P., \& Jumel, K. (1992). L-Ascorbic acid stability in aseptically processed orange juice in TetraBrik cartons and the effect of oxygen. Food Chemistry, 45, 327-31. http://dx.doi.org/10.1016/0308-8146(92)90032-W

Klopotek, Y., Otto, K., \& Bohm, V. (2005). Processing strawberries to different products alters contents of vitamin C, total phenolics, total anthocyanins and antioxidant capacity. Journal of Agricultural and Food Chemistry, 53, 5640-5646. http://dx.doi.org/10.1021/jf047947v

Leong, S. Y., \& Oey, I. (2012). Effect of endogenous ascorbic acid oxidase activity and stability on vitamin C in carrots (Daucus carota subsp. sativus) during thermal treatment. Food Chemistry, 134, 2075-85. http://dx.doi.org/10.1016/j.foodchem.2012.04.002

Li, H., Zhao, L., Wu, J., Zhang, Y., \& Liao, X. (2012). Inactivation of natural microorganisms in litchi juice by high-pressure carbon dioxide combined with mild heat and nisin. Food Microbiology, 30, 139-145. 
http://dx.doi.org/10.1016/j.fm.2011.10.007

Lim, J. (2011). Hedonic scaling: A review of methods and theory. Food Quality and Preference, 22, 733-747. http://dx.doi.org/10.1016/j.foodqual.2011.05.008

Liu, Y., Hu, X., Zhao, X., \& Song, H. (2012). Combined effect of high pressure carbon dioxide and mild heat treatment on overall quality parameters of watermelon juice. Innovative Food Science \& Emerging Technologies, 13, 112-119. http://dx.doi.org/10.1016/j.ifset.2011.11.001

Müller, A., Noack, L., Greiner, R., Stahl, M. R., \& Posten, C. (2014). Effect of UV-C and UV-B treatment on polyphenol oxidase activity and shelf life of apple and grape juices. Innovative Food Science and Emerging Technologies, 26, 498-504. http://dx.doi.org/10.1016/j.ifset.2014.05.014

Ou, B., Hampsch-Woodill, M., \& Prior, R. L. (2001). Development and validation of an improved oxygen radical absorbance capacity assay using fluorescein as the fluorescent probe. Journal of Agricultural and Food Chemistry, 49, 4619-4626. http://dx.doi.org/10.1021/jf010586o

Roig, M. G., Bello, J. F., Rivera, Z. S., \& Kennedy, J. F. (1999). Studies on the occurrence of non-enzymatic browning during storage of citrus juice. Food Research International, 32, 609-619. http://dx.doi.org/10.1016/S0963-9969(99)00128-3

Saxena, S., Hajare, S. N., More, V., Kumar, S., Wadhawan, S., Parte, M. N. P., Gsutam, S., \& Sharma, A. (2011). Antioxidant and radioprotective properties of commercially grown litchi (Litchi chinensis) from India. Food Chemistry, 126, 39-45. http://dx.doi.org/10.1016/j.foodchem.2010.10.051

Singleton, V., \& Rossi, J. (1965). Colorimetry of total phenolics with phosphomolybdicphosphotungstic acid reagents. American Journal of Enology and Viticulture, 16, 144-158.

Trewhella, M. J., \& Grint A. (1988). Condensation of phenolic groups during coal liquefaction model compound studies. Fuel, 67, 1135-1138. http://dx.doi.org/10.1016/0016-2361(88)90383-3

Turkyilmaz, M., \& Ozkan, M. (2014). Effects of condensed tannins on anthocyanins and colour of authentic pomegranate (Punica granatum L.) juices, Food Chemistry, 164, 324-331. http://dx.doi.org/10.1016/j.foodchem.2014.05.048

Walkling-Ribeiro, M., Noci, F., Cronin, D. A., Lyng, J. G., \& Morgan, D. J. (2009). Shelf life and sensory evaluation of orange juice after exposure to thermosonication and pulsed electric fields. Food and Bioproducts Processing, 87, 102-107. http://dx.doi.org/10.1016/j.fbp.2008.08.001

Williams, R. C., Sumner, S. S., \& Golden, D. A. (2005). Inactivation of Escherichia coli O157:H7 and Salmonella in apple cider and orange juice treated with combinations of ozone, dimethyl dicarbonate, and hydrogen peroxide. Journal of Food Science, 70, M197-M201. http://dx.doi.org/10.1111/j.1365-2621.2005.tb07188.x

Wu, Y., Cui, S.W., Tang, J., \& Gu, X. (2007). Optimization of extraction process of crude polysaccharides from boat-fruited sterculia seeds by response surface methodology. Food Chemistry, 105(4), 1599-1605. http://dx.doi.org/10.1016/j.foodchem.2007.03.066

Xu, Y., Wen, J., \& Xiao G. (2014). Effect of thermal and ultra high pressure treatments on quality characteristics of litchi juice, Journal of Anhui Agriculture Science (P. R. China), 42(31), 11078-11082.

Yang, S., Li, B., Liu, W., Mei, C., \& Wu, Y. (2010). Study on quality of litchi juice treated by ultra-high pressure and heat processing, Science and Technology of Food Industry (P. R. China), 31(1), 95-99.

Yeh, L. L., Kim, K. O., Chompreeda, P., Rimkeeree, H., Yaud, N. J. N., \& Lundahl, D. S. (1998). Comparison in Use of The 9-Point Hedonic Scale Between Americans, Chinese, Koreans, and Thai. Food Quality and Preference, 9, 413-419. http://dx.doi.org/10.1016/S0950-3293(98)00028-7

Yingsangaa, P., Srilaonga,V., Kanlayanarat, S., Noichindab, S., \& McGlassonc, W. B. (2008). Relationship between browning and related enzymes (PAL, PPO and POD) in rambutan fruit (Nephelium lappaceum Linn.) cvs. Rongrien and See-Chompoo. Postharvest Biology and Technology, 50, 164-168. http://dx.doi.org/10.1016/j.postharvbio.2008.05.004

Yu, Y., Wu, J., Xiao, G., Xu, Y., Tang, D., Chen, Y., \& Zhang Y. (2013b). Combined effect of dimethyl dicarbonate (DMDC) and nisin on indigenous microorganisms of litchi juice and its microbial shelf life. Journal of Food Science, 78, M1236-1241. http://dx.doi.org/10.1111/1750-3841.12215

Yu, Y., Xiao, G., Wu, J., Xu, Y., Tang, D., Chen, Y., Wen, J., \& Fu, M. (2013a). Comparing characteristic of 
banana juices from banana pulp treated by high pressure carbon dioxide and mild heat. Innovative Food Science \& Emerging Technologies, 18, 95-100. http://dx.doi.org/10.1016/j.ifset.2012.12.003

Zeng, X., Chen, X., Qin, G., \& Zhang, L. (2008). Composition Analysis of Litchi Juice and Litchi Wine. International Journal of Food Engineering, 4(4), 1-18. http://dx.doi.org/10.2202/1556-3758.1379

Zhang, D., \& Quantick P. C. (1997). Effects of chitosan coating on enzymatic browning and decay during postharvest storage of litchi (Litchi chinensis Sonn.) fruit. Postharvest Biology and Technology, 12, 195-202. http://dx.doi.org/10.1016/S0925-5214(97)00057-4

Zhang, X., Chen, F., \& Wang, M. (2013). Impacts of selected dietary polyphenols on caramelization in model systems. Food Chemistry, 141, 3451-3458. http://dx.doi.org/10.1016/j.foodchem.2013.06.053

Zhao, L., Wang, S., Liu, F., Dong, P., Huang, W., Xiong, L., \& Liao, X. (2013). Comparing the effects of high hydrostatic pressure and thermal pasteurization combined with nisin on the quality of cucumber juice drinks. Innovative Food Science and Emerging Technologies, 17, 27-36. http://dx.doi.org/10.1016/j.ifset.2012.10.004

\section{Copyrights}

Copyright for this article is retained by the author(s), with first publication rights granted to the journal.

This is an open-access article distributed under the terms and conditions of the Creative Commons Attribution license (http://creativecommons.org/licenses/by/3.0/). 